Marquette University

e-Publications@Marquette

Theology Faculty Research and Publications

Theology, Department of

$1-1-2014$

\title{
Primordial Lights: The Logos and Adoil in the Johannine Prologue and 2 Enoch
}

Andrei Orlov

Marquette University, andrei.orlov@marquette.edu

Accepted version. "Primordial Lights: The Logos and Adoil in the Johannine Prologue and 2 Enoch," in Revealed Wisdom. Ed. John Ashton. Leiden: Brill, 2014: 99-115. DOI. (C) 2014 Brill. Used with permission. 


\title{
Primordial Lights: The Logos and Adoil in the Johannine Prologue and 2 Enoch $^{1}$
}

\author{
Andrei A. Orlov \\ Theology Department, Marquette University \\ Milwaukee, WI
}

\section{Introduction}

The Gospel of John begins with the Prologue, the hymn containing complex and unique protological imagery. In contrast to the opening chapters of Genesis which center on the creation of the world and humankind, it attempts to unveil the realities that preceded the beginning of the creational process. This emphasis on preexistent realities is very rare in early Jewish lore and found only in a few extrabiblical apocalyptic accounts. Despite the uniqueness of such imagery not all of these apocalyptic writings have received proper attention from scholars of the Fourth Gospel. As Christopher Rowland notes, "little attempt has been made to relate the gospel to the earlier apocalyptic texts of Judaism which either antedate the gospel or are roughly contemporary with it." 2

One such early Jewish text that deals with preexistent matters but has been consistently ignored by Johannine scholars is 2 
(Slavonic) Enoch, a Jewish pseudepigraphon written in the first century CE before the destruction of the Second Jerusalem Temple, just few years earlier than the Fourth Gospel. ${ }^{3}$ Like the Johannine Prologue this Jewish writing attempts to unveil the state of affairs that preceded the creation of the world by depicting an enigmatic character - the luminous aeon Adoil - as the deity's helper at creation. Despite some striking parallels with the Prologue's imagery, however, this Jewish apocalypse has been routinely neglected by major commentators and students of the Fourth Gospel. Such absence of interest is striking since most Jewish narratives contemporary to the Johannine Prologue rarely speak about preexistent mediators assisting the deity at creation.

The aim of this paper is to explore more closely the protological developments found in 2 Enoch and their similarities with the imagery of the Prologue of John.

\section{Enoch}

Protological descriptions, including the details of the creation of the world and humankind, represent one of the main conceptual centers found in Jewish apocalyptic accounts, since protology is so closely connected with eschatology. Many of these elaborations continue the narrative trajectory implicit already in the formative stories found in the initial chapters of the Book of Genesis. Some of these accounts, like the Johannine Prologue, attempt to go beyond the boundaries of conventional biblical imagery and initiate their readers into the details of the reality that preceded the visible creation.

2 Enoch belongs to this unique group of early Jewish texts that divulges the realities that preceded the genesis of the world. In chapters 24-25 of 2 Enoch the deity reveals to the patriarch Enoch, the translated antediluvian hero, some unique details in the mysteries of creation found neither in earlier Enochic booklets nor in any other Second Temple Jewish materials. One of the important parts of this revelation concerns the order of events before the visible creation. The deity tells the seer that prior to visible creation he summoned the luminous aeon Adoil from non-being, ordering him to become the foundation of all created things. It describes Adoil's transmutation into

Revealed Wisdom, (2014): pg. 99-115. DOI. This article is @ Brill and permission has been granted for this version to appear in e-Publications@Marquette. Brill does not grant permission for this article to be further copied/distributed or hosted elsewhere without the express permission from Brill. 
the cornerstone of creation on which the deity establishes his throne. Both shorter and longer recensions of 2 Enoch provide an extensive description of this revelation. In the longer recension of 2 Enoch 24-25 the account has the following form:

Before anything existed at all, from the very beginning, whatever exists I created from the non-existent, and from the invisible the visible. Listen, Enoch, and pay attention to these words of mine! For not even to my angels have I explained my secrets, nor related to them their origin, nor my endlessness (and inconceivableness), as I devise the creatures, as I am making them known to you today. For, before any visible things had come into existence, I, the one, moved around in the invisible things, like the sun, from east to west and from west to east. But the sun has rest in himself; yet I did not find rest, because everything was not yet created. And I thought up the idea' of establishing a foundation, to create a visible creation. And I commanded the lowest things: "Let one of the invisible things descend visibly!" And Adoil descended, extremely large. And I looked at him, and, behold, in his belly he had a great light. And I said to him, "Disintegrate yourself, Adoil, and let what is born from you become visible." And he disintegrated himself, and there came out a very great light. And I was in the midst of the [great] light. And light out of light is carried thus. And the great age came out, and it revealed all the creation which I had thought up to create. And I saw how good it was. And I placed for myself a throne, and I sat down on it. And then to the light I spoke: "You go up higher (than the throne), and be solidified [much higher than the throne], and become the foundation of the higher things." And there is nothing higher than the light, except nothing itself. And again I bowed (?) myself and looked upward from my throne. ${ }^{4}$

The shorter recension of 2 Enoch 24-25 provides a slightly different description:

Before anything existed at all, from the very beginning, whatever is I created from non-being into being, and from the invisible things into the visible. And not even to my angels have I explained my secrets, nor related to them their composition, nor my endless and inconceivable creation which I conceived, as I am making them known to you today. Before any visible things had come into existence, and the light had not yet opened up, I, in the midst of the light, moved around in the 
NOT THE PUBLISHED VERSION; this is the author's final, peer-reviewed manuscript. The published version may be accessed by following the link in the citation at the bottom of the page.

invisible things, like one of them, as the sun moves around from east to west and from west to east. But the sun has rest; yet I did not find rest, because everything was not yet created. And I thought up the idea of establishing a foundation, to create a visible creation. And I commanded the lowest things: "Let one of the invisible things come out visibly!" And Adail descended, extremely large. And I looked at him, and, behold, in his belly he had a great age. And I said to him, "Disintegrate yourself, Adail, and let what is disintegrated from you become visible." And he disintegrated himself, and there came out from him the great age. And thus it carried all the creation which I had wished to create. And I saw how good it was. And I placed for myself a throne, and I sat down on it. To the light I spoke: "You go up higher and be solidified and become the foundation for the highest things." And there is nothing higher than the light, except nothing itself. And I spoke, I straightened myself upward from my throne. ${ }^{5}$

Adoil, a luminous aeon and here the central character of the story, is envisioned in the text as God's helper who brings the whole creation into existence. ${ }^{6}$ In the Slavonic apocalypse, Adoil is not merely a created entity but rather an agent of creation. ${ }^{7}$ The portrayal of the whole creation emerging from Adoil's body further affirms the role of this character as the generating force of creation. ${ }^{8}$ He belongs to the class of the "invisible things" that existed before creation. He therefore does not appear during the process of creation but is "summoned" by the deity from the circle of "invisible things," a feature that provides an additional indication of his preexistence. Instead of familiar biblical "let there be," postulating creation ex nihilo, the readers of the Slavonic apocalypse hear quite different formulae, such as "let one invisible things come out visibly." The text's emphasis on the "descent" of Adoil before his participation in God's project might serve as an indication of his initial exalted status, the state that is also implied at the end of the narrative where God orders the light of Adoil to go higher than the deity's throne. Adoil's exact status remains shrouded in mystery. Although he is portrayed as one of the "invisible things," it is unclear if the text understands him as an angelic or a divine being or as a part of the divine Pleroma. A possible suggestion of the divine nature of Adoil comes from the shorter recension of 2 Enoch 24 which places God in the midst of the invisible preexistent things: "Before any visible things had come into existence, and the light had not yet opened up, I, in the midst of the light, moved around

Revealed Wisdom, (2014): pg. 99-115. DOI. This article is @ Brill and permission has been granted for this version to appear in e-Publications@Marquette. Brill does not grant permission for this article to be further copied/distributed or hosted elsewhere without the express permission from Brill. 
in the invisible things, like one of them, as the sun moves around from east to west and from west to east." This depiction of the deity "moving around" like the sun in the "invisible things" is reminiscent of a solar system in which God is envisioned as a chief luminary and the "invisible things" possibly as planets. Such a depiction might denote the divine nature of the "invisible things" which are understood as "lesser deities" or circles of the divine Pleroma.

In the unfolding drama of creation Adoil is portrayed as God's servant, obediently executing the deity's commands and acting strictly according to the wishes of his master: "And thus it carried all the creation which I had wished to create." The account leaves the impression that Adoil might be envisioned here as a demiurgic hand of the deity. Reflecting on the etymology of Adoil's name Robert Henry Charles proposed that it might derived from the Hebrew אל יד, translated as the "Hand of God."9 Jarl Fossum offers additional insights into the demiurgic connotation of Adoil's name by noting that "it was a Jewish doctrine that God had created the world and man with his very hand(s), and the creative Hand of God even seems to have been hypostasized."10 This tradition of the demiurgic extremities of the deity received prominent development in the later Jewish lore where EnochMetatron is often understood as the deity's hypostatic hand or his hypostatic finger. ${ }^{11}$

It is noteworthy that unlike in Genesis 1 , where the deity fashioning the visible world and his creatures by his direct commands, in the Slavonic apocalypse, God chooses to act via a preexistent mediator, who is envisioned in the text as an anthropomorphic figure. The anthropomorphic qualities of Adoil are hinted in the text in a reference to his belly. He is depicted as one who nurses the whole creation inside his preexistent body and then, like a mother, births the created order. All of creation literally emerges from his broken body, envisioned in 2 Enoch as a disintegration of the primordial anthropomorphic vessel that gives birth to everything. ${ }^{12}$

Another important feature of Adoil is his association with light. The shorter recension suggests that the hidden preexistent light was concealed in Adoil's belly. ${ }^{13}$ The luminous nature of the primordial aeon

Revealed Wisdom, (2014): pg. 99-115. DOI. This article is (C Brill and permission has been granted for this version to appear in e-Publications@Marquette. Brill does not grant permission for this article to be further copied/distributed or hosted elsewhere without the express permission from Brill. 
is especially evident in the longer recension, since it portrays the deity bathing in the light produced from Adoil's disintegration.

Similar to the demiurgic light, darkness in 2 Enoch is also envisioned as a preexistent and demiurgic entity ${ }^{14}$ and has its own personified agent - Arkhas or Arukhas, who is portrayed as the foundation of "lowest things."

The shorter recension of 2 Enoch 26:13 provides the following portrayal of Arukhas:

And I called out a second time into the lowest things, and I said, 'Let one of the invisible things come out solid and visible.' There came out Arukhas, solid and heavy and very black. And I saw how suitable he was. And I said to him, 'Come down low and become solid! And become the foundation of the lowest things!' And he came down and became solid. And he became the foundation of the lowest things. And there is nothing lower than the darkness, except nothing itself. ${ }^{15}$

In this account Arukhas is envisioned similarly to Adoil, an aeonic demiurgic "vessel" of darkness who gives birth to all lower things. Like the aeon of light Arukhas belongs to the class of the preexistent "invisible things," and is likewise not created but "summoned." The aeonic creational processions are similar in both cases, as Arukhas also gives birth by "opening himself up." It is possible that Adoil and Arukhas are understood as the personifications of the preexistent light and darkness which paradoxically reflect each other. Despite such mirroring the deity clearly prefers the realm of Adoil. Disintegration of Adoil provides the foundation (Slav. основание) on which God establishes the first visible manifestation of the created order - his throne.

Another significant feature is Adoil's designation as a "revealer" found in the longer recension. His revelations are understood as not verbal but rather "ontological" disclosures: "And the great age came out, and it revealed all the creation which I had thought up to create."

The traditions about Adoil and Arukhas, two personified primordial helpers, assisting the deity in bringing the world into

Revealed Wisdom, (2014): pg. 99-115. DOI. This article is @ Brill and permission has been granted for this version to appear in e-Publications@Marquette. Brill does not grant permission for this article to be further copied/distributed or hosted elsewhere without the express permission from Brill. 
existence invite some reflection about the mediatorial proclivities of 2 Enoch. It appears that the deity's aids at creation in the Slavonic apocalypse are not exhausted by the figures of Adoil and Arukhas but include other candidates. Although scholars have previously noted that the epilogue of the creational account emphasizes that God is sole creator who does not have adviser and successor to his creation, it does not deny the demiurgic assistants. Other studies have noticed that in 2 Enoch's creational account God's wisdom and his word ${ }^{16}$ are also mentioned as the agents of creation. ${ }^{17}$ Indeed, in both recensions ${ }^{18}$ of 2 Enoch 30:8 the deity commands his wisdom to create man. ${ }^{19}$ Like Adoil and Arukhas at the very beginning of creation, another demiurgic mediator, Sophia, is commissioned to help the deity with the later stages of the creational process by assisting him in the creation of humankind. Scholars often see the Sophia traditions as the formative bedrock for later Jewish mediatorial developments including the Johannine Prologue. ${ }^{20}$ A reference to Sophia as God's helper in 2 Enoch 30 is important for our study since it points to the complex creational universe of the Slavonic apocalypse, a Jewish text that strives to accommodate several mediatorial trends. It is intriguing that in both cases (Adoil and Sophia) the demiurgic agents act as the deity's servants who fulfill "commands" of their master. In 2 Enoch 30:8 the deity narrates to the seer that he "commanded" his wisdom to create man. This expression recalls Adoil's account where the luminous aeon also receives a "command" from God: "And I commanded (повельх) the lowest things: "Let one of the invisible things descend visibly!" And Adoil descended, extremely large." Both passages use the identical Slavonic terminology (Slav. повельх). The reference to the divine word, which is mentioned along with Sophia ${ }^{21}$ as a demiurgic agent in 2 Enoch $33: 4^{22}$ also might demonstrate that the authors of the Slavonic apocalypse appear to be cognizant not only of early traditions of the demiurgic wisdom but also with later Jewish and Christian conceptual currents similar to those found in the Prologue of John, where the wisdom traditions were conflated with the tradition of the divine Name.

\section{Johannine Prologue}

Before proceeding to the analysis of some conceptual parallels between the Logos and Adoil in the Fourth Gospel and 2 Enoch, one

Revealed Wisdom, (2014): pg. 99-115. DOI. This article is @ Brill and permission has been granted for this version to appear in e-Publications@Marquette. Brill does not grant permission for this article to be further copied/distributed or hosted elsewhere without the express permission from Brill. 
general similarity between two accounts deserves our attention. It appears that despite their uniqueness both accounts are deeply affected by the imagery found in Genesis 1 where one can find the familiar oppositions of visible and invisible, darkness and light, categories that also play a paramount role in the Johannine and Enochic accounts. The opening phrase of the Jonannine hymn, "in the beginning" ( $\dot{\varepsilon} \vee$ ápxñ), also present in 2 Enoch' creational account, ${ }^{23}$ evokes Genesis' story. Although in Genesis the expression "in the beginning" pertains to the creation of the world, the phrase, both in 2 Enoch and in the Prologue, is related to pre-creational realities. Regarding the Johannine Prologue, Raymond Brown notes that "...the opening words of verse one are similar to Genesis $1: 1$. While the author of Genesis is referring to creation, the author of the Fourth Gospel is speaking of eternity. There is no indication that the Word is a part of God's created order."24

\section{God's Helpers in Creation}

It appears that like 2 Enoch, the Prologue understands the Logos not as an independent "creator" but rather as a creational agent whose task is to execute God's thoughts, plans and wishes. As demonstrated earlier, in 2 Enoch the deity himself affirms the "executive" nature of Adoil by saying that the luminous aeon carried all the creation which he "had wished to create." The same pattern is discernible in the Fourth Gospel where the Logos is envisioned not as a demiurge but rather as the helper of the Father. Scholars have noted that the Prologue makes it quite clear that "God is the Creator; his Word is the agent." 25 Raymond Brown suggests that "in saying that it is through the Word that all things came into being, the Prologue is at distance from Gnostic thought whereby a demiurge and not God was responsible for material creation, which is evil. Since the Word is related to the Father and the Word creates, the Father may be said to create through the Word. Thus, the material world has been created by God and is good." 26 Personifying both Adoil and the Logos further highlights the distance between the deity and his "helpers." 27 At the same time both accounts stress that their preexistent mediators are active creative participants, not simply dull tools of the deity. Brown observes that "...the role of the Word is not a passive, but an active one. The Logos functions." 28 Similarly in 2 Enoch Adoil's active

Revealed Wisdom, (2014): pg. 99-115. DOI. This article is (C) Brill and permission has been granted for this version to appear in e-Publications@Marquette. Brill does not grant permission for this article to be further copied/distributed or hosted elsewhere without the express permission from Brill. 
participation is hinted by his depiction as the "mother" of all creation, a caregiver that "nurses" the whole creation in the preexistent time and then gives birth to it.

\section{Preexistent Beings}

Another common feature is that both the existence of the Logos and Adoil precedes the act of creation, not made during its process. The exact origin of both mediators is unknown. Although both protological accounts start with the phrase "in the beginning," it does not signify the starting point of creation like the biblical story; instead, it brings the reader in the midst of preexistent divine reality. Both agents are therefore understood as a part of the divine realm. Brown rightly points out that the presence of the Logos "in beginning" unlike in Genesis "refers to the period before creation and is a designation, more qualitative than temporal, of the sphere of God."29

\section{Concealed Entities}

In both accounts the revelations of Adoil and the Logos are wrapped in language of concealment and understood as the utmost divine mysteries. The deity in 2 Enoch tells the seventh antediluvian hero that even his angels lack access to this revelation. ${ }^{30}$ Here the mediatorial agents who helped the deity to bring the world into existence remain hidden from creation, which includes even celestial creatures. In the Prologue, a similar idea can be found, that the one through whom the world came into being remained hidden from the world. ${ }^{31}$ It also appears that in both accounts the esoteric knowledge about preexistent realities eventually becomes revealed to elect humans - in 2 Enoch to the seventh antediluvian hero and his adepts, and in the Prologue to those who believe in Christ. In both cases the revelation of the preexistent realities has a soteriological value that provides the key to the mystery of salvation. ${ }^{32}$ It is therefore not coincidental that in 2 Enoch the disclosure about Adoil is conceptually tied to the revelation about the final "age," an entity that mirrors the primordial aeon of light.

Revealed Wisdom, (2014): pg. 99-115. DOI. This article is (C Brill and permission has been granted for this version to appear in e-Publications@Marquette. Brill does not grant permission for this article to be further copied/distributed or hosted elsewhere without the express permission from Brill. 


\section{Personified Demiurgic Lights}

Both accounts also associate their chief creational agents with preexistent light. It has been already demonstrated in our study that in 2 Enoch Adoil is understood not merely as a luminous entity but as a bearer of the preexistent demiurgic light. He like the Logos in the Prologue, is a source of light himself. The fact that both light and "all creation" are situated in the belly of Adoil further elucidates that the light of the primordial aeon is indeed the demiurgic light.

In the Prologue of John similar developments can be discerned where the Logos is portrayed as the personification of the divine light. ${ }^{33}$ Scholars previously noted that "the equivocal equivalence of the Word and the Light systems is established in the Prologue, where both are identified as agents of creation $(1: 3,10)$, both enter the world $(1: 4,9-10,14)$ and, implicitly, both are the objects of 'receiving,' 'knowing,' and 'believing.'"34 Such depiction of the light as an agent of creation indicates that we deal here, like in 2 Enoch, with the concept of the demiurgic light.

It is also noteworthy that like the Logos, who is understood as the source of both preexistent and "material" light, "light of the world," Adoil is also associated with both luminous entities, expressed in the longer recension of the Slavonic apocalypse as "carrying light out of light."

In John 1:5 the symbolism of light is conflated with the imagery of darkness like in Genesis 1. Yet, such juxtaposition of the light and darkness is reminiscent not only of the imagery found in the first chapter of Hebrew Bible but also peculiar correspondences reflected in 2 Enoch where the light of Adoil is juxtaposed with the darkness of the another primordial aeon - Arukhas, which clearly separated from its luminous counterpart.

\section{Ontological Revealers}

It appears also that both Adoil and the Logos are understood as revealers. Rudolph Bultmann suggested that "the hymn that forms the basis of the Prologue praises the Logos as the Revealer." 35 Indeed, in

Revealed Wisdom, (2014): pg. 99-115. DOI. This article is @ Brill and permission has been granted for this version to appear in e-Publications@Marquette. Brill does not grant permission for this article to be further copied/distributed or hosted elsewhere without the express permission from Brill. 
case of the Logos the revelatory potentials are already manifested even in the title of this divine agent, his designation as the Word of God. ${ }^{36}$ The "revelations" of the Word are ontological disclosures as well as "verbal" ones. As Raymond Brown notes, "the fact that the Word creates means that creation is an act of revelation. All creation bears the stamp of God's Word...."37 The entire creative process is understood in this conceptual framework as a continuous revelation of the deity. The same concept is encountered in the Slavonic apocalypse where Adoil's activity at creation is envisioned as the ontological revelation of God. The longer recension of 2 Enoch designates Adoil as the "revealer." His revelations, however, encompass "ontological" disclosure made manifest, as with the Logos, in his creative work. Adoil's disintegration is identified in the text as the revelation of the created order: "And the great age came out, and it revealed all the creation which I had thought up to create."

The ontological revelations of Adoil and the Logos might also be reflected in the peculiar metamorphoses of both characters when their preexistent forms become shepherded into the realities of the material world. Adoil's transformation is manifested through his disintegration, when this vessel of light bursts, giving life to all creation, while the Logos' incarnation, expressed in the Prologue as the Word becoming flesh, demonstrates his.

\section{Sources of All Creation}

Another notable feature is that both accounts underscore the comprehensiveness of the creational efforts of their preexistent mediators. John 1:3 states that through the divine Logos "all things came into being ... and without him not one thing came into being." The expression "all things" (nóvTa) found in this passage is often understood by the interpreters as a reference to "all the creation."38 Brown notes that beginning with the 2nd century, the phrase "'all things came into being' has been taken as a reference to creation ....

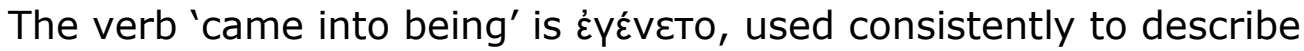
creation in the LXX of Gen 1." 39

The tradition found in John 1:3 can be compared with the testimony about Adoil found in both recensions of 2 Enoch 25 which

Revealed Wisdom, (2014): pg. 99-115. DOI. This article is $\subset$ Brill and permission has been granted for this version to appear in e-Publications@Marquette. Brill does not grant permission for this article to be further copied/distributed or hosted elsewhere without the express permission from Brill. 
tells that Adoil "... carried all the creation (Slav. всю тварь) which I had wished to create." 40 This statement is rather puzzling since a few verses later Arukhas is also depicted as the one who brings the "lower things" into existence. Such discrepancies might reflect the creational narrative's composite nature, as it attempts to reconcile several demiurgic mediatorial trends.

It is also important that both accounts understand their respective creational agents as the demiurgic "vessels" that conceal the whole creation inside of them. In Adoil's case the whole creation is said to be contained in the belly of the primordial aeon. A similar conceptual development might also be present in the Fourth Gospel. Some scholars have proposed that the Prologue indicates that creation was initially hidden in the Logos, a tradition that can be further illuminated by Col 1:16. If the Prologue indeed understands the Logos similarly to Adoil, as the primordial vessel of all created things, it points to a similar conceptual development in which the deity creates the world by emptying his preexistent demiurgic vessels. ${ }^{41}$

\section{Heavenly Men}

Both accounts also hint at the anthropomorphic nature of their respective demiurgic agents, envisioning them as the Heavenly Men. As has been already suggested in our study the Slavonic apocalypse unveils the anthropomorphic nature of Adoil through the portrayal of his light-filled belly. Several studies suggest that Adoil is envisioned in 2 Enoch as the Heavenly Man. April DeConick argues that "the creative activity of the heavenly Man is highlighted in ... the story of Adoil found in 2 Enoch.... where ... a man-like figure, descends with a great light in his stomach." 42 The anthropomorphic nature of Adoil appears to be implied in 2 Enoch 65 where the final aeon, accommodating the remnant of humankind, is envisioned as an eschatological replica of Adoil. Such eschatological gathering is reminiscent of the sculpturing of the "Last Statue" in the Manichaean tradition where the righteous remnant is predestined to reconstitute the anthropomorphic form of the Heavenly Man at the end of the world. ${ }^{43}$

Similar to Adoil's imagery found in Slavonic apocalypse, the Logos is also envisioned as an anthropomorphic entity and, more

Revealed Wisdom, (2014): pg. 99-115. DOI. This article is (C) Brill and permission has been granted for this version to appear in e-Publications@Marquette. Brill does not grant permission for this article to be further copied/distributed or hosted elsewhere without the express permission from Brill. 
precisely, as the Heavenly Man. This understanding of the Logos as an anthropomorphic figure is a pre-Christian development, clearly documented already in Philo's writings where the Logos is portrayed as the Heavenly Man.

Analyzing the Logos' speculations found in Philo's De Confusione Linguarum, ${ }^{44}$ Thomas Tobin argues that in these passages "the Logos has been identified with the figure of the 'heavenly man.'"45 Underlying the creational mold of such imagery Tobin suggests that this important conceptual development "has taken place in the Hellenistic Jewish interpretation of the Logos in connection with interpretations of texts from Genesis 1-3." 46 Tobin concludes that "this assimilation in Hellenistic Judaism of the Logos to the figure of the heavenly man may have served as an important step in the kind of reflection that led to the identification of the Logos with a particular human being, Jesus of Nazareth, in the hymn in the Prologue of John." 47

\section{Demarcations of Light and Darkness}

The symbolism of opposition of light and darkness plays equally important role both in 2 Enoch and the Prologue of John. Much ink has been spilled about the antithetical relation between light and darkness in the Johannine hymn. ${ }^{48}$ Thomas Tobin, among others, notes that "... a second element in the hymn that moves beyond the viewpoints found in Jewish wisdom literature is the stark contrast between light and darkness ... found in John 1:4-5."49 The Prologue insists that the darkness has not been able to overcome the light. Such strict delineation between light and darkness once again brings to mind 2 Enoch, in which darkness is not only clearly separated from light but even has its own personification in the figure of Arukhas.

It seems that both in 2 Enoch and the Prologue Adoil and the Logos might serve not only the personifications of the light, but also the demarcations or the "walls" whose functions are to prevent the mixing of the light and the darkness. When the shorter recension of 2 Enoch 65 speaks about the luminosity of the final eschatological aeon that mirrors Adoil this imagery is conflated with the symbolism of the wall: "But they will have a great light for eternity, <and> an indestructible wall...." 50

Revealed Wisdom, (2014): pg. 99-115. DOI. This article is @ Brill and permission has been granted for this version to appear in e-Publications@Marquette. Brill does not grant permission for this article to be further copied/distributed or hosted elsewhere without the express permission from Brill. 
NOT THE PUBLISHED VERSION; this is the author's final, peer-reviewed manuscript. The published version may be accessed by following the link in the citation at the bottom of the page.

\section{Conclusion}

It has been long recognized that the Prologue of John was influenced by the wisdom traditions. However, the complex question about the exact mold of the sapiential currents that influenced the author of the hymn still remains unanswered. John Ashton notes that "we do not need to ask from what source the author of the hymn derived his ideas, for both the general theme and the specific details are abundantly illustrated in wisdom tradition. Rather we have to ask what there was in the tradition which could have stimulated his own imaginative response: what precisely did he take from it?"151

The same can be asked of 2 Enoch's own appropriation of the wisdom traditions. ${ }^{52}$ It appears that while the tradition of the demiurgic wisdom is hidden within the Logos speculation in the Prologue, the Slavonic apocalypse clearly separates it from Adoil's deeds by invoking the actions of Sophia in the creation of humankind later in the text. This postulation of several demiurgic mediators points to the composite nature of the creational account of 2 Enoch in which various mediatorial streams are forced to interact. Another important feature of 2 Enoch's creational account is its peculiar mediatorial pairs: in the beginning Adoil is coupled with Arukhas, and in the conclusion Wisdom is paired with the Word. The last pair is especially noteworthy since it evokes the Johannine account where the wisdom traditions are conflated with the imagery of the divine Word. It has been previously noted that the Prologue seems to be influenced by a particular mold of the sapiential tradition that emphasizes the aural revelation of the deity; Nicola Frances Denzey argues that the Prologue remains a representative example not simply a Wisdom tradition, "but rather of a distinct 'Word tradition' which shared sapiental literature's dependency on Genesis yet interpreted it rather differently. This tradition attributed a creative force not to God's hypostasized forethought or Wisdom, but to his Voice or Word." 53 While the Prologue, like Philo, conflates the aural tradition of the divine Word with the anthropomorphic ideology of the Heavenly Man, it appears that in 2 Enoch these two conceptual streams remain clearly separated. ${ }^{54}$ Moreover, in the Slavonic apocalypse the deity uses a plethora of various demiurgic "instruments," aural as well as anthropomorphic. While in the beginning he forcefully creates with his luminous form by bursting the

Revealed Wisdom, (2014): pg. 99-115. DOI. This article is @ Brill and permission has been granted for this version to appear in e-Publications@Marquette. Brill does not grant permission for this article to be further copied/distributed or hosted elsewhere without the express permission from Brill. 
anthropomorphic vessel of the primordial light which gives birth to everything, he later chooses to mold humankind with other helper - his Wisdom, the mediator who is paired in 2 Enoch with the divine Word but, unlike in the Prologue, not entirely fused with it. These intriguing interactions provide a unique glimpse into the complex world of Jewish mediatorial debates of the late Second Temple period, the conceptual developments that played formative role in both the Slavonic apocalypse and the Johannine hymn.

\section{Notes}

${ }^{1}$ It is a source of great pleasure to be able to contribute an article for a volume honoring Professor Christopher Rowland, a scholar from whom I have learned so much.

2 C. Rowland, "John 1.51, Jewish Apocalyptic and Targumic Tradition," NTS 30 (1984) 498-507 at 500.

${ }^{3}$ On date of 2 Enoch see R. H. Charles, and W. R. Morfill, The Book of the Secrets of Enoch (Oxford: Clarendon Press, 1896) xxvi; C. Böttrich, Das slavische Henochbuch (JSHRZ, 5; Gütersloh: Gütersloher Verlaghaus, 1995) 813; A. Orlov, "The Sacerdotal Traditions of 2 Enoch and the Date of the Text," in: New Perspectives on 2 Enoch: No Longer Slavonic Only (eds. A. Orlov, G. Boccaccini, J. Zurawski; Studia Judaeoslavica, 4; Leiden: Brill, 2012) 103-116.

${ }^{4}$ F. Andersen, "2 (Slavonic Apocalypse of) Enoch", The Old Testament Pseudepigrapha (2 vols.; ed. J.H. Charlesworth; New York: Doubleday, 1985 [1983]) 1.142-144.

5 Andersen, "2 Enoch," 1.143-145.

${ }^{6}$ On the etymology of the name Adoil see A. Orlov, "Secrets of Creation in 2 (Slavonic) Enoch," in: idem, From Apocalypticism to Merkabah Mysticism: Studies in the Slavonic Pseudepigrapha (SJSJ 114; Leiden: Brill, 2007) 191-94.

7 Alan Segal, among others, reflects on the demiurgic role of Adoil by noting that "some relationship between God's principal angel and His agent at creation may be possible in traditions about the angel Adoil...." A. Segal, Two Powers in Heaven: Early Rabbinic Reports about Christianity and Gnosticism (SJLA, 25; Leiden: Brill, 1977) 189. April DeConick also sees Adoil as a demiurgic agent. She notes that "the creative activity of the heavenly Man

Revealed Wisdom, (2014): pg. 99-115. DOI. This article is (C) Brill and permission has been granted for this version to appear in e-Publications@Marquette. Brill does not grant permission for this article to be further copied/distributed or hosted elsewhere without the express permission from Brill. 
is highlighted in another Jewish Alexandrian source, the story of Adoil found in 2 Enoch." A. DeConick, Recovering the Original Gospel of Thomas: A History of the Gospel and Its Growth (London: T\&T Clark, 2005) 201.

8 Some scholars have difficulties seeing these demiurgic qualities of Adoil. Masanobu Endo argues that although Adoil is personified and function as one who obeys the command of God he is not an agent but rather an object which is transformed and created. Endo notes that "both Adoil and Arkhas are personified and function as those who obey the command of God; however they are not described as the agents, but rather as the objects which are transformed and created." M. Endo, Creation and Christology: A Study on the Johannine Prologue in the Light of Early Jewish Creation Accounts (WUNT, 2.149; Tübingen: MohrSiebeck, 2002) 21.

9 The Apocrypha and Pseudepigrapha of the Old Testament (ed. R. H. Charles; 2 vols.; Oxford: Clarendon Press, 1913) 2.445.

10 J. Fossum, The Name of God and the Angel of the Lord: Samaritan and Jewish Concepts of Intermediation and the Origin of Gnosticism (WUNT, 36; Tübingen: Mohr-Siebeck, 1985) 288.

11 See Sifre to Deuteronomy. Pisqa 338. Sifre to Deuteronomy. An Analytical Translation (tr. J. Neusner; BJS 101; 2 vols., Atlanta: Scholars, 1987) 2.392. Cf. also 3 Enoch 48D (Synopse §§7780).

12 Some additional details about the nature and qualities of Adoil can be also found in chapter 65 of 2 Enoch where the beginning of creation becomes invoked again in the context of the mysteries of the last days. Scholars have previously noted that the protological account in 2 Enoch 25, dealing with the establishment of the created order, appears to correspond with the order of eschatological events in chapter 65 where during his short visit to earth Enoch conveys to his children some eschatological secrets. The patriarch reveals that in the eschatological time all the righteous of the world will be incorporated into one single luminous entity: the aeon of the righteous. The description of this final aeon bears some striking similarities to the primordial aeon Adoil depicted in chapter 25. In view that the last aeon in many ways restores and mirrors the first aeon and the depiction of the last aeon provides

Revealed Wisdom, (2014): pg. 99-115. DOI. This article is (C) Brill and permission has been granted for this version to appear in e-Publications@Marquette. Brill does not grant permission for this article to be further copied/distributed or hosted elsewhere without the express permission from Brill. 
additional hints to the qualities and nature of Adoil. The patriarch begins his narration with references to the familiar theme of the primeval aeon already encountered in chapter 25. These protological events are then set in parallel with the chain of eschatological events that, according to the authors of the apocalypse, will reintegrate the remnant of the creation - an elite group of humans - into a single aeon which will collect all the righteous of the world. It appears that the righteous here, like in later Jewish mysticism, are understood as gatherers of the divine light dispersed during the disintegration of Adoil who will collect the primordial light into a new eschatological vessel. The final consummation of the chosen creation into a single aeon reversely mirrors the initial protological disintegration of Adoil which once gave birth to the multiplicity of created forms. This eschatological depiction, which reflects the protological realities, again demonstrates Adoil's preexistence. The portrayal of the final aeon underlines its atemporal nature by telling that "then the time periods will perish, and there will be neither years nor months nor days, and hours will no longer be counted." Andersen, "2 Enoch," 1.191-193. The final aeon also reaffirms the anthropomorphic qualities of Adoil since it will be eschatologically reassembled from the remnant of humankind.

13 "the light had not yet opened up."

${ }^{14}$ Endo rightly observes that "... darkness is pre-existent at the beginning of creation, and it is the foundation of the lowest things." Endo, Creation and Christology, 22.

15 Andersen, "2 Enoch," 1.145. The longer recension of 2 Enoch 26:1-3 offers a similar depiction: "And I called out a second time into the very lowest things, and I said, 'Let one of the invisible things come out visibly, solid.' And Arkhas came out, solid and heavy and very red. And I said, 'Open yourself up, Arkhas, and let what is born from you become visible!' And he disintegrated himself. There came out an age, dark, very large, carrying the creation of all lower things. And I saw how good it was. And I said to him, 'Come down low and become solid! And become the foundation of the lowest things!' And it came about. And he came down and became solid. And he became the foundation of the lowest things. And there is nothing lower than the darkness, except nothing itself." Andersen, "2 Enoch," 1.144.

Revealed Wisdom, (2014): pg. 99-115. DOI. This article is @ Brill and permission has been granted for this version to appear in e-Publications@Marquette. Brill does not grant permission for this article to be further copied/distributed or hosted elsewhere without the express permission from Brill. 
162 Enoch 33:4 (longer recension) reads: "And there is no adviser and no successor to my creation. I am self-eternal and not made by hands. My thought is without change. My wisdom is my adviser and my deed is my word." Andersen, "2 Enoch," 1.156.

17 Endo, Creation and Christology, 22.

18 The shorter recension of 2 Enoch 30:8 reads: "When I had finished all this, I commanded (повельх) my wisdom to create man." Andersen, "2 Enoch," 1.151. The longer recension of 2 Enoch 30:8 reads: "And on the sixth day I commanded (повельх) my wisdom to create man out of the seven components." Andersen, "2 Enoch," 1.150.

${ }^{19}$ It should be mentioned that already in Wis. 9:2 and Wis. 10:1-2, Wisdom is responsible for the formation, protection, deliverance, and strengthening of the protoplast: "...[who] by your wisdom have formed humankind," "Wisdom protected the first-formed father of the world, when he alone had been created; she delivered him from his transgression, and gave him strength to rule all things."

${ }^{20}$ For example, Charles Kingsley Barrett suggests that "Col 1:15-20 shows as clearly as does John 1:1-18 the use of language drawn from Jewish speculations about Wisdom." C.K. Barrett, The Gospel According to St. John (2nd ed.; London: SPCK, 1978) 154.

${ }^{21}$ Martin Hengel notes that already in Wis 9:1 "... the creative word of God and the personified Sophia appear in a parallelismus membrorum: 'O God of my fathers Lord of mercy who hast made all things by thy word and by thy wisdom hast formed man.' Word and wisdom of God are here nearly identified ...." M. Hengel, "The Prologue of the Gospel of John as the Gateway to Christological Truth," in: The Gospel of John and Christian Theology (eds. R. Bauckham and C. Mosser; Grand Rapids: Eerdmans, 2008) 265-294 at 274.

22 "And there is no adviser and no successor to my creation... My wisdom is my adviser and my deed is my word." Andersen, "2 Enoch," 1.156.

${ }^{23}$ Cf. 2 Enoch 24: "Before anything existed at all, from the very beginning (испръва)." Andersen, "2 Enoch," 1.142.

24 R. Brown, "The Prologue of the Gospel of John," Review and Expositor 62 (1965) 429-439 at 430-31. 
25 F.F. Bruce, The Gospel of John: Introduction, Exposition and Notes (Grand Rapids: Eerdmans, 1994) 32.

26 Brown, The Gospel According to John I-XII, 26.

27 Frank Bruce notes that "... our Evangelist has no mere literary personification in mind. The personal status which he ascribes to the Word is a matter of real existence; the relation which the Word bears to God is a personal relation: 'the Word was with God.'" Bruce, The Gospel of John: Introduction, Exposition, and Notes, 30.

28 Brown, "The Prologue of the Gospel of John," 431.

29 Brown, The Gospel According to John I-XII, 4.

302 Enoch 24 (the shorter recension): "...and not even to my angels have I explained my secrets, nor related to them their composition, nor my endless and inconceivable creation which I conceived, as I am making them known to you today." Andersen, "2 Enoch," 1.143.

31 John 1:10: "He was in the world, and the world came into being through him; yet the world did not know him." (NRSV).

32 Reflecting on the Prologue's "mystery" language Paul Lamarche underlines its soteriological dimension. He suggests that "if we compare John with the Pauline corpus we find that the Logos corresponds exactly to the mystery which, for Paul, is embodied in the divine person of Christ. And it is probably no accident that in one passage in Paul the words 'logos' and 'mystery' are found side by side; it is not Paul's mission, 'which was given to me for you [the Colossians], to make the word of God (ton logon tou theou) fully known, the mystery (to mystērion) hidden for ages and generations but now made manifest' (Col. 1:25f.). No doubt the Pauline Logos and Johannine are not identical; nevertheless the link established by Paul between the Word of God and mystery can pave the way for a more profound understanding of the Word as mystery - inner word, hidden mystery, plan of God." P. Lamarche, "The Prologue of John," in: The Interpretation of John (2nd ed.; ed. J. Ashton; Edinburgh: T\&T Clark, 1997) 47-66 at 53.

33 Peder Borgen notes that "John 1:1-8 seems to draw on learned Jewish exegesis, wherein Logos, אבר and light, אור are connected on the basis of Gen. 1:3." P. Borgen, "Logos Was the True Light:

Revealed Wisdom, (2014): pg. 99-115. DOI. This article is @ Brill and permission has been granted for this version to appear in e-Publications@Marquette. Brill does not grant permission for this article to be further copied/distributed or hosted elsewhere without the express permission from Brill. 
Contributions to the Interpretation of the Prologue of John," NovT 14 (1972) 115-130 at 192.

34 N.R. Petersen, The Gospel of John and Sociology of Light: Language and Characterization in the Fourth Gospel (Valley Forge: Trinity Press International, 1993) 72.

35 R. Bultmann, The Gospel of John. A Commentary (Philadelphia: Westminster, 1971) 32.

${ }^{36}$ Barrett notes that the choice of the term logos points both to the demiurgic and revelatory roles, the functions already associated with this terminology in the Greek Old Testament. He notices that logos "is a very frequent word in the Greek Old Testament; here special attention may be drawn to two groups of passages. In the former the word is creative ... in the latter, the word of the Lord is the prophet's message, that is, the means by which God communicates his purpose to his people ... Both creation and revelation are in mind in the Johannine Prologue, and the rest of the gospel encourages us to suppose that the influence of the Old Testament may be found here." Barrett, The Gospel According to St. John, 153.

37 Brown, The Gospel According to John I-XII, 25.

38 J. Ashton, Studying John: Approaches to the Fourth Gospel (Oxford: Clarendon, 1994) 20-21.

39 Brown, The Gospel According to John I-XII, 6. He further noticed

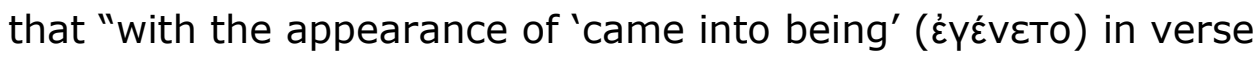
3 we are in the sphere of creation. All that is created is intimately related to the Word, for it was created not only through him, but also in him. We find the same idea in the hymn of Col 1. 16: 'For in him were all things created ... all things were created by him and in him.' The same unity that exists between the Word and his creation will be applied in John 15:5 to Jesus and the Christian: 'Apart from me you can do nothing.'" Brown, The Gospel According to John I-XII, 25.

40 Andersen, "2 Enoch," 1.144-145.

${ }^{41} \mathrm{Cf}$. Phil 2:5-8: "Let the same mind be in you that was in Christ Jesus, who, though he was in the form of God, did not regard equality with God as something to be exploited, but emptied himself, taking the form of a slave, being born in human likeness. And being found in human form, he humbled himself 
NOT THE PUBLISHED VERSION; this is the author's final, peer-reviewed manuscript. The published version may be accessed by following the link in the citation at the bottom of the page.

and became obedient to the point of death-- even death on a cross." (NRSV).

42 DeConick, Recovering the Original Gospel of Thomas, 201. See also A. DeConick, Seek to See Him: Ascent and Vision Mysticism in the Gospel of Thomas (VCSup., 33; Leiden: Brill, 1996) 66-67.

${ }^{43}$ Cf. Keph. 165: "Again, when the sun sinks from the universe and sets, and all people go in to their hiding places and houses and conceal themselves; this also pertains to the mystery of the end, as it presages the consummation of the universe. For, when all the light will be purified and redeemed in the universe at the last, the collector of all things, the Last Statue, will gather in and sculpt itself. It is the last hour of the day, the time when the Last Statue will go up to the aeon of light." The Kephalaia of the Teacher: the Edited Coptic Manichaean Texts in Translation with Commentary (ed. I. Gardner; NHMS, 37; Leiden: Brill, 1995) 174. Cf. also Keph. 104: "The first death is from the time when the light fell to the darkness, and was mixed in with the rulers of darkness; until the time when the light will become pure, and be separated from the darkness in that great fire. The reminder left behind there can build and add to the Last Statue." The Kephalaia of the Teacher, 107-108. On the Manichaean eschatological "Statue" made from the particles of light rescued by the elect, see G. Widengren, Mani and Manichaeism (New York: Holt, Rinehart and Winston) 68; M. Heuser, "Manichaean Myth According to the Coptic Sources," in: M. Heuser and H.-J. Klimkeit, Studies in Manichaean Literature and Art (NHMS, 46; Leiden: Brill, 1998) 3-108 at 86-87.

${ }^{44} \mathrm{Cf}$. Conf. 41: "... you who have enrolled yourself as children of one and the same Father, who is not mortal but immortal - God's

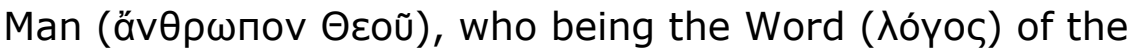
Eternal...." Philo (10 vols.; trs. F. H. Colson and G. H. Whitaker; LCL; Cambridge, Massachusetts: Harvard University Press, 1929-1964) 4.32-33; Conf. 146: "And many names are his, for he is called, 'the Beginning,' and the Name of God, and His Word (入óyos), and the Man after His image ..." Philo, 4.88-91.

45 T. Tobin, "The Prologue of John and Hellenistic Jewish Speculation," CBQ 52 (1990) 252-69 at 267. Alan Segal also notes that already "Philo identifies the heavenly man with the Logos, which

Revealed Wisdom, (2014): pg. 99-115. DOI. This article is @ Brill and permission has been granted for this version to appear in e-Publications@Marquette. Brill does not grant permission for this article to be further copied/distributed or hosted elsewhere without the express permission from Brill. 
is identified with God's archangel and principal helper in creation." Segal, Two Powers in Heaven, 189.

46 Tobin, "The Prologue of John and Hellenistic Jewish Speculation," 267.

47 Tobin, "The Prologue of John and Hellenistic Jewish Speculation," 267.

48 John Painter notes that "in John the darkness and the light are antithetical. Each excludes the other." J. Painter, "Rereading Genesis in the Prologue of John?," in: Neotestamentica et Philonica. Studies in Honor of Peder Borgen (eds. D.E. Aune, T. Seland, J.H. Ulrichsen; Leiden: Brill 2003) 182. On the motif of primordial light and darkness in the Johannine Prologue see also P. Borgen, Philo, John and Paul: New Perspectives on Judaism and Early Christianity (Brown Judaic Studies; Atlanta: Scholars, 1987) 89-92.

49 Tobin, "The Prologue of John and Hellenistic Jewish Speculation," 254.

50 Andersen, "2 Enoch," 1.191-193.

${ }^{51}$ Ashton, "The Transformation of Wisdom," in: Ashton, Studying John, 5-35 at 7.

52 On sapiential traditions in 2 Enoch see A. Orlov, "Adoil Outside the Cosmos: God Before and After Creation in the Enochic Tradition," in: Histories of the Hidden God: Concealment and Revelation in Western Gnostic, Esoteric and Mystical Traditions (eds. A. DeConick and G. Adamson; Gnostica: Texts and Interpretations; London: Equinox, 2013) 30-57.

53 N.F. Denzey, "Genesis Traditions in Conflict? The Use of Some Exegetical Traditions in the Trimorphic Protennoia and the Johannine Prologue," VC 55 (2001) 20-44 at 28.

54 The tension between aural and anthropomorphic manifestations of the deity can be traced already to the Hebrew Bible where the anthropomorphic imagery of the Priestly tradition was contested by the aural paradigm of the divine Name promulgated by the Deuteronomic school. On the tensions between the paradigms of the divine Name and the divine Form in biblical materials see $M$. Weinfeld, Deuteronomy and the Deuteronomic School (Oxford: Clarendon Press, 1972) 191-201;T.N.D. Mettinger, The Dethronement of Sabaoth. Studies in the Shem and Kabod Theologies (ConBOT, 18; Lund: Wallin \& Dalholm, 1982) 124.

Revealed Wisdom, (2014): pg. 99-115. DOI. This article is @ Brill and permission has been granted for this version to appear in e-Publications@Marquette. Brill does not grant permission for this article to be further copied/distributed or hosted elsewhere without the express permission from Brill. 